\title{
ANALISIS PENGARUH CURRENT RATIO, DEBT TO EQUITY RATIO, TOTAL ASSET TURNOVER, NET PROFIT MARGIN TERHADAP RETURN ON EQUITY PADA PERUSAHAAN PROPERTI DAN REAL ESTATE YANG TERDAFTAR DI BURSA EFEK INDONESIA TAHUN 2013-2017
}

\author{
Vonny \\ Program Studi Magister Manajemen Universitas Tarumanagara \\ tvonnyp@gmail.com
}

\begin{abstract}
In its development, current financial statements are not only used to present the amount of profit that can be obtained in a certain period, but also can show indicators of financial performance of a company. To be able to measure the financial performance of a company, a financial statement analysis is needed, where one type of technical financial statement analysis can be done using financial ratio analysis. Users of financial statements, including shareholders can measure the effectiveness and efficiency of capital management carried out by company management by measuring the size of profitability, namely Return on Equity, which is the dependent variable tested in this study. This study aims to determine how the effect of Liquidity Ratio (Current Ratio), Leverage Ratio (Debt to Equity Ratio), Activity Ratio (Total Asset Turnover) and Profitability Ratio (Net Profit Margin) both partially and simultaneously to Profitability Ratio (Return on Equity). The object of this study is the Property and Real Estate companies listed on the Indonesia Stock Exchange in the period 2013-2017. The determination of the sample used in this study was purposive sampling using multiple regression models. The results of this study indicate that both partially and simultaneously, Current Ratio, Debt to Equity Ratio, Total Asset Turnover and Net Profit Margin have a significant effect on Return on Equity.
\end{abstract}

Keywords : Current Ratio, Debt to Equity Ratio, Total Asset Turnover, Net Profit Margin, Return on Equity of Property and Real Estate Companies

Abstrak : Dalam perkembangannya, laporan keuangan saat ini tidak hanya digunakan untuk menyajikan jumlah laba yang dapat diperoleh dalam periode tertentu, namun juga dapat menunjukkan indikator kinerja keuangan suatu perusahaan. Untuk dapat mengukur kinerja keuangan suatu perusahaan diperlukan suatu analisis laporan keuangan, dimana salah satu jenis teknis analisis laporan keuangan dapat dilakukan dengan menggunakan analisis rasio keuangan. Pengguna laporan keuangan, termasuk didalamnya pemegang saham dapat mengukur efektivitas dan efisiensi pengelolaan modal yang dilakukan oleh manajemen perusahaan dengan mengukur besar kecilnya profitabilitas, yaitu Return on Equity, dimana merupakan variabel dependen yang diuji dalam penelitian ini. Penelitian ini bertujuan untuk mengetahui bagaimana pengaruh Liquidity Ratio (Current Ratio), Leverage Ratio (Debt to Equity Ratio), Activity Ratio (Total Asset Turnover) dan Profitability Ratio (Net Profit Margin) baik secara parsial maupun secara simultan terhadap Profitability Ratio (Return on Equity).Obyek penelitian ini adalah perusahaan Properti dan Real Estate yang terdaftar di Bursa Efek Indonesia dalam periode tahun 2013-2017. Penentuan sample yang digunakan dalam penelitian ini adalah purposive sampling dengan menggunakan model regresi berganda. Hasil penelitian ini menunjukkan bahwa baik secara parsial maupun secara simultan, Current Ratio, Debt to Equity Ratio, Total Asset Turnover dan Net Profit Margin mempunyai pengaruh yang signifikan terhadap Return on Equity.

Kata Kunci : Current Ratio, Debt to Equity Ratio, Total Asset Turnover, Net Profit Margin, Return on Equity pada perusahaan properti dan real estate. 


\section{PENDAHULUAN}

Di dalam perekonomian suatu negara, perlu didukung oleh pelaku bisnis, yaitu dalam hal ini perusahaan, dimana perusahaan mempunyai fungsi menjalankan roda perekonomian melalui perdagangan yaitu transaksi jual dan beli. Perusahaan adalah bentuk badan usaha yang didirikan untuk mencapai tujuan tertentu. Salah satu tujuan dari perusahaan adalah untuk mendapatkan laba. Penulis memfokuskan penelitian pada Perusahaan Terbuka yang terdaftar di Bursa Efek Indonesia, dimana perusahaan dalam hal ini, dimiliki oleh para pemegang saham dan dikelola oleh professional. Berdasarkan hal tersebut, tujuan perusahaan dapat berkembang bukan hanya untuk mencapai keuntungan maksimal saja, namun juga untuk mensejahterahkan kepentingan para pemegang saham.

Dalam rangka untuk mensejahterahkan kepentingan para pemegang saham, perlu diperhatikan indikator-indikator penting untuk menilai kinerja suatu perusahaan. Alat untuk menilai kondisi dan/atau kinerja suatu perusahaan baik atau buruk, yaitu melalui analisa laporan keuangan. Menurut Sukamulja (2017), investor dapat melakukan evaluasi keuangan perusahaan melalui berbagai macam cara, setiap analisis memiliki tujuan tertentu. Misalnya, analisis rasio digunakan untuk mengetahui likuiditas, solvabilitas, maupun profitabilitas perusahaan; analisis tren untuk mengetahui kecenderungan penjualan ataupun laba perusahaan dari tahun ke tahun; dan analisis struktur modal untuk mengetahui proporsi liabilitas dan ekuitas terhadap aset perusahaan Selain itu, seorang investor dalam melakukan investasi tidak hanya memperhatikan kondisi keuangan dan nilai suatu perusahaan, tetapi juga harus membandingkan perusahaan yang dievaluasi dengan industri, sektor dan peer group. Hal ini dikarenakan kondisi suatu perusahaan yang terlihat baik bisa saja lebih rendah nilainya dibandingkan perusahaan lain dalam sektor maupun subsektor yang sama.

Menurut Sukamulja (2017) "Analisis laporan keuangan merupakan prosedur/langkah teknis yang diperlukan untuk menilai kualitas perusahaan sebelum memutuskan untuk membeli saham (bisnis) perusahaan tersebut". Menurut Sudana (2011), Rasio keuangan yang dihitung dari laporan keuangan perusahaan pada satu tahun saja tidak akan memberikan informasi memadai. Untuk memperoleh informasi yang banyak, analis keuangan dapat melakukan analisis dengan cara cross-section, yaitu membandingkan rasio keuangan suatu perusahaan dengan rasio keuangan perusahaan lain atau industry pada suatu periode waktu yang sama, dan time series yaitu membandingkan atau mengevaluasi kecenderungan (trend) rasio keuangan suatu perusahaan dari waktu ke waktu. Menurut Sudana (2011), penggunaan utang dalam pembelanjaan investasi perusahaan dapat mempengaruhi kemampuan perusahaan untuk menghasilkan laba atas modal yang digunakan (Return on Equity atau ROE).

Berdasarkan latar belakang yang dijelaskan sebelumnya, penulis ingin melakukan penelitian dengan judul : "Analisis Pengaruh Current Ratio, Debt to Equity Ratio, Total Asset Turnover, Net Profit Margin terhadap Return on Equity pada Perusahaan Properti dan Real Estate yang terdaftar di Bursa Efek Indonesia Tahun 2013-2017”.

\section{TINJAUAN LITERATUR}

Dalam menjalankan suatu perusahaan, manajemen harus menetapkan perencanaan keuangan jangka panjang. Rencana keuangan merupakan pernyataan mengenai apa yang akan dilakukan perusahaan pada masa yang akan datang. Untuk menyusun suatu rencana keuangan, manajemen harus menetapkan beberapa elemen kebijakan keuangan perusahaan berikut (Sudana, 2011):

1. Investasi dalam aktiva baru yang dibutuhkan perusahaan. Hal ini tergantung pada peluang investasi yang akan dipilih untuk dilaksanakan oleh perusahaan, dan terkait dengan keputusan penganggaran modal atau capital budgeting decisions.

2. Tingkat Leverage keuangan yang akan dilaksanakan oleh perusahaan. Hal ini akan menentukan berapa dana yang harus dipinjam untuk mendanai investasi dalam aktiva tetap, dan terkait dengan struktur modal perusahaan. 
3. Jumlah kas yang diperlukan untuk membayar pemegang saham. Hal ini terkait dengan kebijakan dividen perusahaan.

4. Jumlah likuiditas dan modal kerja yang dibutuhkan untuk menjamin kelangsungan operasi perusahaan. Hal ini terkait dengan keputusan tentang modal kerja perusahaan.

Menurut Sudana (2011) :

"Keempat keputusan perusahaan ini secara langsung akan mempengaruhi profitabilitas, kebutuhan pendanaan dari luar perusahaan, dan peluang pertumbuhan di masa yang akan datang serta terdapat hubungan langsung antara pertumbuhan dan kebutuhan pendanaan eksternal, dan ROE merupakan komponen yang penting dalam menentukan tingkat pertumbuhan berkelanjutan perusahaan".

Merujuk pada penelitian sebelumnya, variabel-variabel yang mempengaruhi Return on Equity diantaranya adalah Current Ratio (Hantono:2015), Debt to Equity Ratio (Salim:2015, Hendawati:2017, Kurniasih, dkk:2015, Hantono:2015, Pongrangga et al:2015), Total Asset Turnover (Pongrangga et al:2015), Net Profit Margin (Kurniasih, dkk:2015). Hipotesis penelitian ini adalah ingin mengetahui apakah Current Ratio, Debt to Equity Ratio, Total Asset Turnover dan Net Profit Margin mempunyai pengaruh secara parsial terhadap Return on Equity.

\section{METODOLOGI PENELITIAN}

Data yang dibutuhkan dalam penelitian ini terdiri dari :

1. Data perusahaan properti dan real estate yang terdaftar di Bursa Efek Indonesia selama periode 2013-2017.

2. Data ROE pada perusahaan properti dan real estate yang terdaftar di Bursa Efek Indonesia pada periode tahun 2013-2017.

3. Data rasio-rasio keuangan pada perusahaan properti dan real estate yang terdaftar di Bursa Efek Indonesia pada periode tahun 2013-2017.

Adapun sumber data yang digunakan dalam penelitian ini adalah :

1. Website PT. Bursa Efek Indonesia (http://www.idx.co.id/).

2. Website IDN Financials (https://www.idnfinancials.com).

3. Annual Report perusahaan-perusahaan properti dan real estate yang terdaftar di Bursa Efek Indonesia secara berturut-turut selama periode penelitian (Tahun 2013-2017).

Populasi yang digunakan dalam penelitian ini adalah seluruh perusahaan properti dan real estate yang terdaftar di Bursa Efek Indonesia pada tahun 2013 sampai 2017. Dari seluruh populasi yang ada, akan diambil beberapa perusahaan yang akan dijadikan sampel. Pengambilan sampel dilakukan berdasarkan metode purposive sampling dengan tujuan untuk mendapatkan sampel yang representatif sesuai dengan kriteria sampel, yaitu :

1. Saham perusahaan properti dan real estate yang terdaftar di Bursa Efek Indonesia secara berturut-turut selama periode penelitian (Tahun 2013-2017).

2. Perusahaan properti dan real estate yang menerbitkan Laporan Keuangan yang telah diaudit per 31 Desember pada periode penelitian (Tahun 2013-2017).

3. Perusahaan properti dan real estate yang selalu menghasilkan laba atau tidak mengalami kerugian selama periode penelitian.

4. Perusahaan properti dan real estate tersebut menyertakan hutang jangka panjang dalam memenuhi kebutuhan dananya selama periode penelitian.

5. Data keuangan yang dibutuhkan dapat diperoleh di laporan keuangan selama kurun waktu penelitian yaitu tahun 2013-2017. 
Model Regresi Data Panel untuk penelitian ini dirumuskan sebagai berikut :

$$
\mathrm{Y}=\mathrm{a}+\mathrm{b} 1 \mathrm{X} 1+\mathrm{b} 2 \mathrm{X} 2+\mathrm{b} 3 \mathrm{X} 3+\mathrm{b} 4 \mathrm{X} 4+\mathrm{e}
$$

Dimana :

$\mathrm{Y}=$ Return on Equity

A $\quad=$ konstanta

b1, b2, b3, b4 = koefisien regresi parsial untuk masing-masing variabel X1, X2, X3, X4

$\mathrm{X} 1=$ Current Ratio $(\mathrm{CR})$

$\mathrm{X} 2=$ Debt to Equity Ratio (DER)

X3 $\quad=$ Total Assets Turnover $($ TATO $)$

X4 = Net Profit Margin (NPM)

$\mathrm{E} \quad=$ Faktor Pengganggu

\section{ANALISIS DAN PEMBAHASAN}

Sampel yang digunakan dalam penelitian ini adalah sebanyak 25 perusahaan properti dan real estate yang terdaftar di Bursa Efek Indonesia pada tahun 2013 sampai 2017. Penulis melakukan uji normalitas data dan uji asumsi klasik untuk memenuhi syarat model regresi liner berganda yang baik. Hasil pengujian penelitian, sebagai berikut :

1. Normalitas menunjukkan nilai signifikansi lebih besar dari 0.05 , maka dapat disimpulkan bahwa residual menyebar normal.

2. Nilai Durbin-Watson sebesar 1.779, sehingga dapat disimpulkan tidak terjadi permasalahan autokorelasi.

3. Nilai VIF < 10, maka tidak terdapat multikolinearitas di antara variabel independent, yaitu Current Ratio, Debt to Equity Ratio, Total Assets Turnover dan Net Profit Margin.

4. Nilai signifikansi dari semua variabel independen (Current Ratio : 0.591, Debt to Equity Ratio : 0.578, Total Assets Turnover : 0.712 dan Net Profit Margin : 0.857) lebih besar dari 0.05 , sehingga dapat disimpulkan, tidak terdapat masalah heteroskedastisitas.

5. Diperoleh persamaan regresi berganda sebagai berikut :

$$
\mathrm{Y}=-0.080-0.008 \mathrm{X} 1+0.051 \mathrm{X} 2+0.429 \mathrm{X} 3+0.311 \mathrm{X} 4+\mathrm{e}
$$

6. Current Ratio dengan nilai -4.615 , mempunyai pengaruh negatif terhadap Return on Equity. Sedangkan Debt to Equity Ratio dengan nilai 8.676, Total Assets Turnover dengan nilai 15.635 dan Net Profit Margin dengan nilai 19.445, mempunyai pengaruh positif terhadap Return on Equity.

7. Nilai $F$ sebesar 206.205 dengan tingkat signifikansi $0.000>0.05$, maka dapat disimpulkan bahwa : Current Ratio, Debt to Equity Ratio, Total Assets Turnover dan Net Profit Margin secara simultan mempunyai pengaruh secara signifikan terhadap Return on Equity.

8. Nilai Adjusted R Square 0.875, menunjukkan Variabel independen dapat menjelaskan variabel dependen sebesar $87.5 \%$, sedangkan $12.5 \%$ dijelaskan oleh faktor lain yang tidak terdapat dalam model.

\section{KESIMPULAN DAN SARAN}

Current Ratio, Debt to Equity Ratio, Total Assets Turnover dan Net Profit Margin secara simultan mempunyai pengaruh secara signifikan terhadap Return on Equity baik itu secara parsial maupun simultan. Penelitian ini memiliki berberapa keterbatasan, yaitu :

1. Sampel yang digunakan adalah perusahaan properti dan real estate yang menunjukkan kinerja baik selama 5 tahun periode penelitian.

2. Variabel bebas yang digunakan dalam penelitian, yaitu Current Ratio, Debt to Equity Ratio, Total Assets Turnover dan Net Profit Margin, dapat menjelaskan variabel dependen hanya sebesar $87.5 \%$. 
Berdasarkan hasil penelitian ini, penulis memiliki saran bagi penelitian berikutnya sebagai berikut :

1. Menggunakan jenis (industri) perusahaan yang berbeda.

2. Dapat menambah rasio keuangan lainnya sebagai variabel bebas.

Bagi Investor dan perusahaan, peneliti memiliki pendapat sebagai berikut :

1. Bagi investor, Hasil penelitian ini dapat memberi masukan agar lebih selektif dalam melakukan investasi. Dimana untuk mendapatkan tingkat pengembalian (return) yang tinggi, investor sebaiknya memperhatikan perkembangan dan keadaan industri dari perusahaan secara keseluruhan, dapat memperhatikan perusahaan yang memiliki perputaran asset yang terus mengalami kenaikan, proporsi utang yang tidak melebihi total aset perusahaan dan aktiva lancar yang tinggi untuk menjamin pembayaran utang lancar serta produktivitas perusahaan.

2. Berdasarkan hasil penelitian ini Current Ratio, Debt to Equity Ratio, Total Assets Turnover dan Net Profit Margin berpengaruh secara signifikan terhadap Return on Equity perusahaan. Sehingga jika perusahaan ingin meningkatkan Return on Equity maka keempat faktor tersebut harus diperhatikan, mulai dari pengelolaan aset dengan efektif untuk menghasilkan penjualan sehingga semakin cepat pengembalian kas, penggunaan utang dalam perusahaan dan likuditas perusahaan untuk mengetahui risiko serta aktiva produktif yang dimiliki.

\section{DAFTAR PUSTAKA}

Astuti, Kurniasih Dwi, Wulan Retnowati, dan Ahmad Rosyid. Universitas Sultan Ageng Tirtayasa. 2015. "Pengaruh Struktur Modal terhadap Profitabilitas (Studi pada perusahaan Go Publik yang menjadi 100 perusahaan terbaik versi Majalah Fortune Indonesia Periode 2010-2012)", dalam Jurnal Akuntansi. Vol. 2 No. 1 Juli 2015.

Basuki, Agus Tri, dan Nano Prawoto. 2016. "Analisis Regresi Dalam Penelitian Ekonomi \& Bisnis (Dilengkapi Aplikasi SPSS \& Eviews)”, Penerbit PT RajaGrafindo Persada, Jakarta.

Hantono. 2015. "Pengaruh Current Ratio dan Debt to Equity Ratio terhadap Profitabilitas pada Perusahaan Manufaktur Sektor Logam dan sejenisnya yang terdaftar di Bursa Efek Indonesia Periode 2009-2013", dalam Jurnal Wira Ekonomi Mikroskil. Volume 5, Nomor 01, April 2015.

Hendawati, Henda. 2017. "Analisis Current Ratio, Debt to Quity Ratio, dan Total Asset Turnover terhadap Return on Equity”, dalam Jurnal SIKAP Vol. 1 (No. 2), 2017, Hal 97111.

Pongrangga, Rizki Adriani, Moch. Dzulkirom, dan Muhammad Saifi. 2015. "Pengaruh Current Ratio, Total Asset Turnover, Debt to Equity Ratio terhadap Retun on Equity (Studi pada Perusahaan Sub Sektor Property dan Real Estate yang Terdaftar di BEI Periode 20112014)", dalam Jurnal Administrasi Bisnis (JAB) Vol. 25 No. 2, Agustus 2015.

Salim, Jihan. 2015. "Pengaruh Leverage (DAR, DER, dan TIER) terhadap ROE Perusahaan Properti dan Real Estate yang terdaftar di perusahaan Bursa Efek Indonesia Tahun 20102014" dalam Perbanas Review Volume 1, Nomor 1, November 2015.

Sudana, I Made. 2011, "Manajemen Keuangan Perusahaan Teori dan Praktik Edisi 2", Penerbit Erlangga. Hal. 20-24, 53-54, 64-65, 158.

Suharli, Michell. 2009, "Pelaporan Keuangan Sesuai dengan Prinsip Akuntansi”. Penerbit : Grasindo, Jakarta. Hal. 3.

Sujarweni, V. Wiratna. "Manajemen Keuangan Teori, Aplikasi dan Hasil Penelitian". Yogyakarta: Pustaka Baru Press. Hal. 25, 27-28, 75-78, 90-98, 110, 115.

Sujarweni, V. Wiratna. Cetakan 2015. "SPSS untuk Penelitian”. Yogyakarta: Pustaka Baru Press. Hal. 103, 116, 181, 186. 
Sukamulja, Prof. Dr. Sukmawati. 2017. "Pengantar Pemodelan Keuangan dan Analisis Pasar Modal”. Penerbit : ANDI, Yogyakarta. Hal. 11, 48-49, 50, 63, 227, 231.

Tabel Durbin-Watson, Direproduksi oleh : Junaidi, http://junaidichaniago.wordpress.com, dari sumber http://www.standford.edu.

Tabel F, Diproduksi oleh : Junaidi, https://junaidichaniago.files.wordpress.com/2010/04/tabelf-0-05.pdf, diakses pada 21 April 2019 Pukul 23.23.

Tabel t, Diproduksi oleh : Junaidi, https://junaidichaniago.files.wordpress.com/2010/04/tabelt.pdf, diakses pada 21 April 2019 Pukul 23.24. 